\author{
УДК 338.45 \\ О РАЗРАБОТКЕ ТИПОВЫХ МОДЕЛЕЙ (РЕКОМЕНДАЦИЙ) РАЗВИТИЯ ОТДЕЛЬНЫХ ТЕРРИТОРИЙ \\ С ВЫСОКОЙ КОНЦЕНТРАЦИЕЙ ПРОМЫШЛЕННОГО ПОТЕНЦИАЛА \\ мария В. Пигунова ${ }^{1, @}$ \\ ${ }^{1}$ Воронежский государственный университет инженерных технологий, 394036, Россия, г. Воронеж, \\ пр. Револющии, 19 \\ @mpigunova@govvrn.ru
}

Поступила в редакциию 08.12.2017. Принята к печати 17.04.2018.

Ключевые слова: промышленность, стратегическое планирование, механизмы стимулирования, территориальное развитие промышленности.

\begin{abstract}
Аннотация: В статье рассматриваются актуальные вопросы стратегического планирования промышленного развития отдельных территорий с высокой концентрацией промышленного потенциала. Автором исследована роль региональных органов власти в оказании методологической поддержки органам местного самоуправления в разработке документов стратегического планирования в сфере промышленности путем разработки типовых моделей (рекомендаций) развития отдельных территорий. Выявлены особенности целеполагания в сфере промышленной политики и определения механизмов стимулирования деятельности промышленных предприятий на региональном и местном уровнях. На основе предложенной системы показателей определены типы экономики муниципальных образований (на примере Воронежской области), охарактеризован их промышленный потенциал, даны рекомендации по стимулированию деятельности в сфере промышленности отдельных муниципальных образований Воронежской области. Сделаны выводы о необходимости обеспечения координации при разработке документов стратегического планирования в сфере промышленного развития на всех уровнях государственного (федерального, регионального) и муниципального управления, об актуальности задач по стандартизации региональной промышленной политики и обеспечению комплексного подхода к рассмотрению ее территориальных аспектов.
\end{abstract}

Для цитирования: Пигунова М. В. О разработке типовых моделей (рекомендаций) развития отдельных территорий с высокой концентрацией промышленного потенциала // Вестник Кемеровского государственного университета. Серия: Политические, социологические и экономические науки. 2018. № 3. С. 149-156. DOI:10.21603/2500-3372-2018-3-149-156.

Одним из принципов промышленной политики, установленным статей 3 Федерального закона от 31.12.2014 № 488-Ф3 «О промышленной политике в Российской Федерации» (далее - Федеральный закон), является координация мер стимулирования деятельности в сфере промышленности, осуществляемых:

- органами государственной власти Российской Федерации,

- органами государственной власти субъектов Российской Федерации,

- органами местного самоуправления.

Органы местного самоуправления являются участниками формирования промышленной политики и ее реализации, наряду с органами государственной власти Российской Федерации, органами государственной власти субъектов Российской Федерации, субъектами деятельности в сфере промышленности, организациями, входящими в состав инфраструктуры поддержки указанной деятельности [1-3].

Органы местного самоуправления вправе осуществлять меры стимулирования деятельности в сфере промышленности на территориях муниципальных об- разований в соответствии с Федеральным законом, законами субъектов Российской Федерации и уставами муниципальных образований. Меры стимулирования могут реализовываться за счет доходов местных бюджетов, за исключением межбюджетных трансфертов, предоставленных из бюджетной системы Российской Федерации, и поступлений налоговых доходов по дополнительным нормативам отчислений [2; 3].

В то же время Федеральный закон от 06.10.2003 № 131-Ф3 «Об общих принципах организации местного самоуправления в Российской Федерации» не предусматривает в числе вопросов местного значения создание условий для развития промышленного производства или решение каких-либо других вопросов в сфере промышленности [4]. Это затрудняет разработку и принятие муниципальных правовых актов по вопросам содействия в развитии (стимулирования на местном уровне) промышленных производств. Данную проблематику следует рассматривать в контексте решения задач по стандартизации региональной промышленной политики (в качестве одного из территориальных аспектов) [5-8, с. 39-40; 9]. 
Примеры отражения вопросов стимулирования деятельности в сфере промышленности в уставах муниципальных образований субъектов Российской Федерации приведены в таблице 1. (Таблица составлена (разработана) автором при поддержке информационно-справочной системы «КонсультантПлюс: Регион»).

Изменения, связанные со вступлением в силу 30 июня 2015 г. Федерального закона от 31.12.2014 № 488-Ф3 «О промышленной политике в Российской Федерации», наиболее полно отражены в Уставах городского округа города Рязань и города Владивосток.
Оказание содействия и поддержки развитию промышленности предусмотрено уставами муниципальных образований городских округов на территории Республики Коми. В Уставе города Тобольска (Тюменская область) отражены полномочия администрации города по разработке и реализации программ развития промышленности. Вопросы непосредственного или косвенного стимулирования развития предприятий промышленных производств содержатся в уставах муниципальных образований Ярославской, Псковской областей, Забайкальского края, Ямало-Ненецкого

Таблица 1. Лучшая практика отражения вопросов стимулирования деятельности в сфере промышленности в уставах муниципальных образований на территории субъектов Российской Федерации

Table 1. The best practice of activity stimulation in the industrial sphere in charters of municipal units on the territory of territorial subjects of the Russian Federation

\begin{tabular}{|c|c|}
\hline Субъекты Российской Федерации & $\begin{array}{c}\text { Вопросы стимулирования деятельности в сфере } \\
\text { промышленности }\end{array}$ \\
\hline $\begin{array}{l}\text { Рязанская область } \\
\text { Устав муниципального образования - } \\
\text { городской округ город Рязань }\end{array}$ & $\begin{array}{l}\text { Статья } 60.1 \text { Осуществление мер стимулирования деятельности в } \\
\text { сфере промышленности на территории муниципального образования - } \\
\text { город Рязань. }\end{array}$ \\
\hline $\begin{array}{l}\text { Приморский край } \\
\text { Устав города Владивостока }\end{array}$ & $\begin{array}{l}\text { Статья 5.1. Вопросы, не отнесенные к вопросам местного значения } \\
\text { города Владивостока, решение которых осуществляется органами } \\
\text { местного самоуправления города Владивостока: осуществление мер } \\
\text { стимулирования деятельности в сфере промышленности на террито- } \\
\text { рии города Владивостока. }\end{array}$ \\
\hline $\begin{array}{l}\text { Республика Коми } \\
\text { Устав муниципального образования } \\
\text { городского округа «Сыктывкар», } \\
\text { Устав муниципального образования } \\
\text { городского округа «Вуктыл» }\end{array}$ & $\begin{array}{l}\text { В сфере осуществления исполнительно-распорядительной деятельно- } \\
\text { сти администрации городского округа глава городского округа - руко- } \\
\text { водитель администрации - оказывает содействие и поддержку разви- } \\
\text { тию промышленности городского округа. }\end{array}$ \\
\hline $\begin{array}{l}\text { Тюменская область } \\
\text { Устав города Тобольска }\end{array}$ & $\begin{array}{l}\text { Полномочия Администрации города Тобольска в области экономиче- } \\
\text { ского планирования и прогнозирования, поддержки малого и среднего } \\
\text { предпринимательства: } \\
\text { - разрабатывает и реализует программы развития промышленности, } \\
\text { - согласовывает размещение объектов промышленности. }\end{array}$ \\
\hline $\begin{array}{l}\text { Забайкальский край } \\
\text { Устав муниципального района } \\
\text { «Балейский район» }\end{array}$ & $\begin{array}{l}\text { Полномочия администрации муниципального района по решению } \\
\text { вопросов местного значения (в области социально-экономического } \\
\text { развития муниципального района, бюджета, финансов и учета): } \\
\text { содействует эффективному взаимодействию научного и промышлен- } \\
\text { ного потенциалов муниципального района, направленных на повыше- } \\
\text { ние эффективности действующих предприятий, созданию новых, на } \\
\text { производство конкурентоспособной продукции. }\end{array}$ \\
\hline $\begin{array}{l}\text { Псковская область } \\
\text { Устав муниципального образования } \\
\text { «Дедовичский район», } \\
\text { Устав муниципального образования } \\
\text { «Локнянский район» }\end{array}$ & $\begin{array}{l}\text { Статья 65. Отношения органов местного самоуправления с предприя- } \\
\text { тиями, учреждениями и организациями, не находящимися в муници- } \\
\text { пальной собственности. Органы местного самоуправления района в } \\
\text { соответствии с законодательством вправе: } \\
\text { - координировать деятельность предприятий, учреждений и органи- } \\
\text { заций, расположенных на территории района, в комплексном социаль- } \\
\text { но-экономическом развитии района; } \\
\text { - содействовать созданию на территории района предприятий } \\
\text { различных форм собственности, занятых обслуживанием населения и } \\
\text { промышленным производством. }\end{array}$ \\
\hline
\end{tabular}




\begin{tabular}{|c|c|}
\hline Субъекты Российской Федерации & $\begin{array}{c}\text { Вопросы стимулирования деятельности в сфере } \\
\text { промышленности }\end{array}$ \\
\hline $\begin{array}{l}\text { Ярославская область } \\
\text { Устав муниципального образования } \\
\text { «Ярославский муниципальный } \\
\text { район» }\end{array}$ & $\begin{array}{l}\text { Администрация района реализует следующие полномочия по реше- } \\
\text { нию вопросов местного значения (в области архитектуры и строитель- } \\
\text { ства, транспорта и связи): привлекает на договорной основе предприя- } \\
\text { тия к участию в развитии мощностей строительной индустрии и } \\
\text { промышленности строительных материалов для производства работ } \\
\text { на территории района. }\end{array}$ \\
\hline $\begin{array}{l}\text { Ямало-Ненецкий автономный округ } \\
\text { Устав муниципального образования } \\
\text { город Ноябрьск }\end{array}$ & $\begin{array}{l}\text { Полномочия Администрации города в сфере отношений недропользо- } \\
\text { вания и использования, охраны, защиты и воспроизводства лесов: } \\
\text { обеспечивает развитие минерально-сырьевой базы для предприятий } \\
\text { местной промышленности. }\end{array}$ \\
\hline
\end{tabular}

и Ханты-Мансийского автономных округов. Наличие на территории муниципального образования стабильно работающих промышленных предприятий с высокопроизводительными рабочими местами является гарантией эффективного решения вопросов занятости, стабилизации численности и роста доходов населения, способствует миграционному приросту.

Предприятия промышленности вносят значительный вклад в формирование наиболее значимого для местных бюджетов налога на доходы физических лиц, а также поступлений от местных налогов (на территории Воронежской области их вклад составляет, соответственно, 21,9\% и 13,5 \% по итогам 2016 г.).

С учетом заинтересованности органов местного самоуправления в фактическом увеличении собственных доходов бюджета муниципального образования, основным источником которых являются налоговые поступления от субъектов предпринимательства, осуществляющих деятельность на территории муниципального образования, в том числе в сфере промышленности, разработаны типовые модели (рекомендации) стимулирования промышленного развития отдельных территорий.

Данные рекомендации могут применяться органами местного самоуправления при разработке документов стратегического планирования и мер стимулирования деятельности в сфере промышленности на территориях муниципальных образований.

Стимулирование деятельности в сфере промышленности осуществляется путем [1-3]:

1) предоставления следующих видов поддержки:

- финансовой (в форме субсидий, налоговых льгот, займов и др.),

- информационно-консультационной,

- поддержки научно-технической деятельности и инновационной деятельности в сфере промышленности,

- поддержки развития кадрового потенциала,

- поддержки внешнеэкономической деятельности;

2) предоставления государственных и муниципальных преференций;
3) предоставления иных мер поддержки, установленных федеральным законодательством, законами субъектов Российской Федерации, уставами муниципальных образований.

В последние годы на региональном и местном уровнях возрастает значимость нефинансовых мер поддержки, в их числе $[2 ; 3]$ :

- информационно-консультационная, методическая поддержка, оказываемая уполномоченными органами в сфере промышленности промышленным предприятиям, осуществляющим деятельность на территории муниципального образования (в частности информирование о мерах стимулирования, действующих на федеральном и региональном уровнях);

- создание условий для кооперации и координации деятельности промышленных предприятий с научными, образовательными организациями, для развития процессов кластеризации в сфере промышленности;

- стимулирование спроса на продукцию местных промышленных производителей, в том числе через систему закупок для государственных и муниципальных нужд;

- формирование органами местного самоуправления инициатив, как правило, в партнерстве с частными промышленными организациями по созданию (развитию) промышленной инфраструктуры и (или) инфраструктуры поддержки деятельности в сфере промышленности, малого и среднего предпринимательства (индустриальных (промышленных) парков, технопарков, промышленных кластеров, инжиниринговых центров) при поддержке федерального бюджета.

Определение приоритетных направлений стимулирования деятельности в сфере промышленности на местном уровне зависит от промышленного потенциала муниципального образования и отраслевой специализации промышленных предприятий, осуществляющих деятельность на его территории (таблицы 2 и 3$)$. 
Таблица 2. Рекомендации по стимулированию деятельности в сфере промышленности на местном уровне Table 2. Recommendations about stimulation of activity in the sphere of the industry at the local level

\begin{tabular}{|c|c|}
\hline $\begin{array}{c}\text { Нормативно-правовое регулирование. Приоритетные меры } \\
\text { стимулирования }\end{array}$ & $\begin{array}{c}\text { Тип экономики муниципального } \\
\text { образования (МО) } \\
\end{array}$ \\
\hline $\begin{array}{l}\text { Отражение в Уставах муниципальных образований изменений, } \\
\text { связанных с реализацией Федерального закона от } 31.12 .2014 \\
\text { № 488-ФЗ «О промышленной политике в Российской Федерации» }\end{array}$ & $\begin{array}{l}\text { Аграрно-индустриальный; } \\
\text { Индустриально-аграрный; } \\
\text { Индустриальный }\end{array}$ \\
\hline $\begin{array}{l}\text { Разработка и реализация документов стратегического планирования } \\
\text { в сфере промышленности }\end{array}$ & Индустриальный \\
\hline $\begin{array}{l}\text { Информирование о мерах стимулирования, действующих на } \\
\text { федеральном и региональном уровнях }\end{array}$ & $\begin{array}{l}\text { Аграрно-индустриальный; } \\
\text { Индустриально-аграрный; } \\
\text { Индустриальный }\end{array}$ \\
\hline $\begin{array}{l}\text { Создание условий для кооперации и координации деятельности } \\
\text { промышленных предприятий с научными, образовательными } \\
\text { организациями, для развития процессов кластеризации в сфере про- } \\
\text { мышленности }\end{array}$ & $\begin{array}{l}\text { Аграрно-индустриальный; } \\
\text { Индустриально-аграрный; } \\
\text { Индустриальный }\end{array}$ \\
\hline $\begin{array}{l}\text { Стимулирование спроса на продукцию местных промышленных } \\
\text { производителей, в том числе через систему закупок для государ- } \\
\text { ственных и муниципальных нужд }\end{array}$ & $\begin{array}{l}\text { Аграрно-индустриальный; } \\
\text { Индустриально-аграрный; } \\
\text { Индустриальный }\end{array}$ \\
\hline $\begin{array}{l}\text { Формирование инициатив по созданию (развитию) промышленной } \\
\text { инфраструктуры и (или) инфраструктуры поддержки деятельности } \\
\text { в сфере промышленности, малого и среднего предпринимательства } \\
\text { при поддержке федерального и регионального бюджета }\end{array}$ & $\begin{array}{l}\text { Индустриально-аграрный; } \\
\text { Индустриальный }\end{array}$ \\
\hline
\end{tabular}

Таблица 3. Характеристика промышленного потенциала отдельных муниципальных образований Воронежской области [10; 11]

Table 3. Characteristic of industrial capacity of separate municipal units in the Voronezh region [10; 11]

\begin{tabular}{|c|c|c|c|c|}
\hline 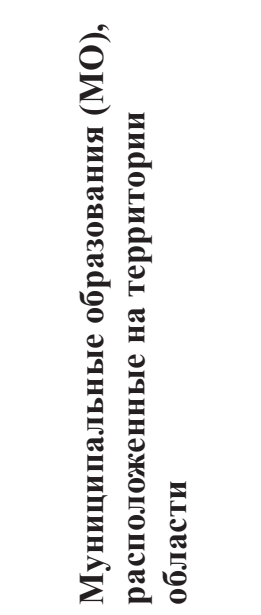 & 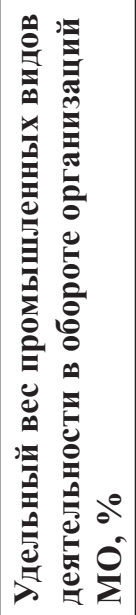 & 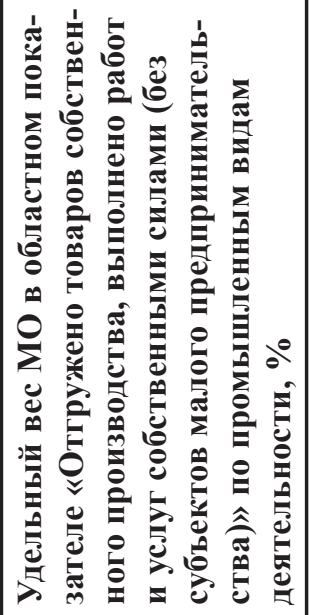 & 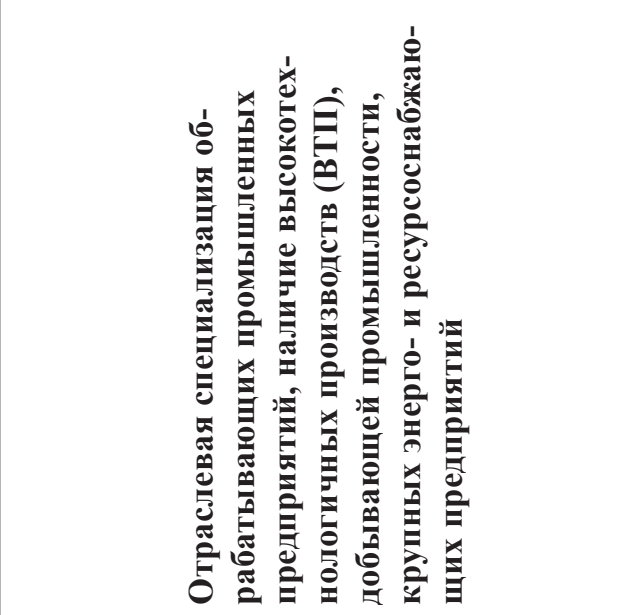 & 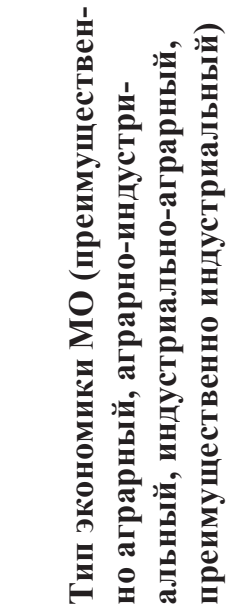 \\
\hline \multicolumn{5}{|c|}{ Муниципальные районы } \\
\hline Аннинский & 47 & 1,66 & Производство пищевых продуктов & $\begin{array}{l}\text { Аграрно-инду- } \\
\text { стриальный }\end{array}$ \\
\hline Бобровский & 64,31 & 3,74 & $\begin{array}{l}\text { Производство пищевых продуктов; } \\
\text { Деревообрабатывающее производство; } \\
\text { Машиностроение (ВТП) (в перспективе } \\
\text { реализуется крупный инвестиционный } \\
\text { проект) }\end{array}$ & $\begin{array}{l}\text { Индустриаль- } \\
\text { но-аграрный }\end{array}$ \\
\hline Бутурлиновский & 58,5 & 0,93 & Производство пищевых продуктов & $\begin{array}{l}\text { Аграрно-инду- } \\
\text { стриальный }\end{array}$ \\
\hline Верхнехавский & 81,56 & 3,02 & $\begin{array}{l}\text { Производство пищевых продуктов; } \\
\text { Производство строительных материалов }\end{array}$ & $\begin{array}{l}\text { Индустриаль- } \\
\text { но-аграрный }\end{array}$ \\
\hline
\end{tabular}




\begin{tabular}{|c|c|c|c|c|}
\hline 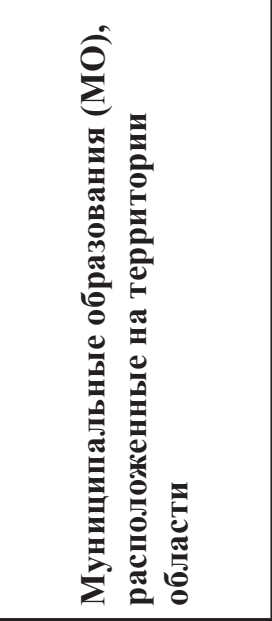 & 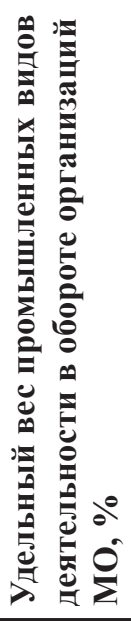 & 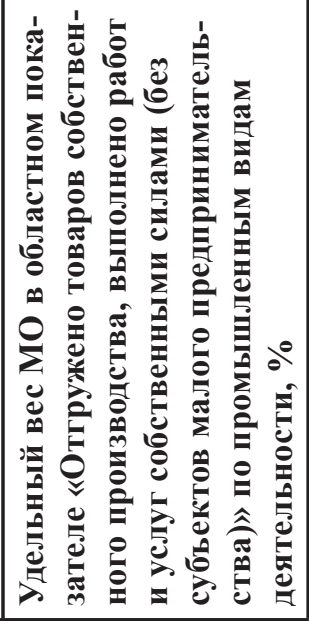 & 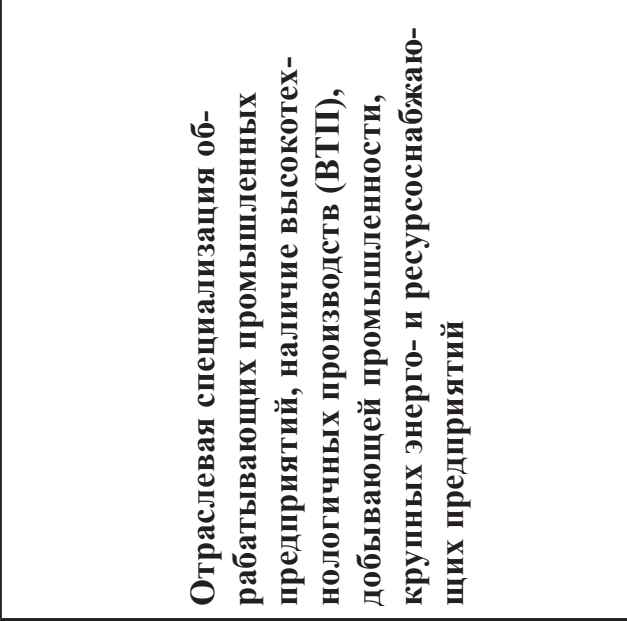 & 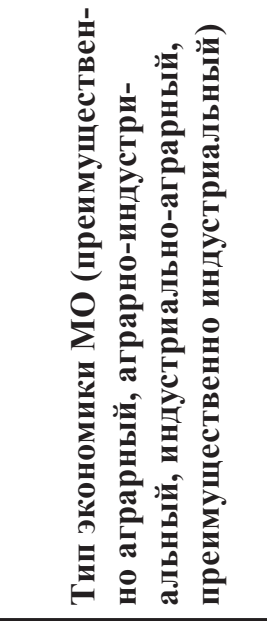 \\
\hline Грибановский & 55,54 & 1,31 & $\begin{array}{l}\text { Машиностроение (ВТП); } \\
\text { Производство пищевых продуктов }\end{array}$ & $\begin{array}{l}\text { Индустриально- } \\
\text { аграрный }\end{array}$ \\
\hline Калачеевский & 15,81 & 1,52 & $\begin{array}{l}\text { Добыча полезных ископаемых; } \\
\text { Производство пищевых продуктов }\end{array}$ & $\begin{array}{l}\text { Аграрно- } \\
\text { индустриальный }\end{array}$ \\
\hline Кантемировский & 12,8 & 0,22 & $\begin{array}{l}\text { Добыча полезных ископаемых; } \\
\text { Машиностроение (ВТП) }\end{array}$ & $\begin{array}{l}\text { Аграрно- } \\
\text { индустриальный }\end{array}$ \\
\hline Лискинский & 45,3 & 6,46 & $\begin{array}{l}\text { Добыча полезных ископаемых; } \\
\text { Металлургическое производство и } \\
\text { производство готовых металлических } \\
\text { изделий; } \\
\text { Машиностроение (ВТП); } \\
\text { Производство строительных материалов; } \\
\text { Производство пищевых продуктов }\end{array}$ & $\begin{array}{l}\text { Индустриально- } \\
\text { аграрный }\end{array}$ \\
\hline Новоусманский & 32,17 & 1,15 & $\begin{array}{l}\text { Производство пищевых продуктов; } \\
\text { Производство электрооборудования, } \\
\text { электронного и оптического оборудова- } \\
\text { ния (ВТП); } \\
\text { Производство строительных материалов }\end{array}$ & $\begin{array}{l}\text { Аграрно- } \\
\text { индустриальный }\end{array}$ \\
\hline Новохоперский & 71,84 & 1,6 & $\begin{array}{l}\text { Добыча полезных ископаемых; } \\
\text { Производство пищевых продуктов; } \\
\text { Производство прочих готовых изделий }\end{array}$ & $\begin{array}{l}\text { Аграрно- } \\
\text { индустриальный }\end{array}$ \\
\hline Острогожский & 16,73 & 0,59 & $\begin{array}{l}\text { Добыча полезных ископаемых; } \\
\text { Производство пищевых продуктов; } \\
\text { Производство электрооборудования, } \\
\text { электронного и оптического оборудова- } \\
\text { ния (ВТП); } \\
\text { Машиностроение (ВТП); } \\
\text { Производство прочих готовых изделий }\end{array}$ & $\begin{array}{l}\text { Аграрно- } \\
\text { индустриальный }\end{array}$ \\
\hline Панинский & 55,7 & 0,57 & $\begin{array}{l}\text { Производство пищевых продуктов; } \\
\text { Металлургическое производство и } \\
\text { производство готовых металлических } \\
\text { изделий } \\
\end{array}$ & $\begin{array}{l}\text { Аграрно-инду- } \\
\text { стриальный }\end{array}$ \\
\hline Поворинский & 65,07 & 0,7 & $\begin{array}{l}\text { Производство пищевых продуктов; } \\
\text { Машиностроение (ВТП) }\end{array}$ & $\begin{array}{l}\text { Индустриаль- } \\
\text { но-аграрный }\end{array}$ \\
\hline Рамонский & 29,31 & 3,44 & $\begin{array}{l}\text { Производство пищевых продуктов; } \\
\text { Производство резиновых и пластмассо- } \\
\text { вых изделий }\end{array}$ & $\begin{array}{l}\text { Аграрно-инду- } \\
\text { стриальный }\end{array}$ \\
\hline Россошанский & 67,58 & 10,26 & $\begin{array}{l}\text { Химическая промышленность (ВТП); } \\
\text { Производство резиновых и пластмассо- } \\
\text { вых изделий; } \\
\text { Производство пищевых продуктов; } \\
\text { Производство строительных материалов }\end{array}$ & $\begin{array}{l}\text { Индустриаль- } \\
\text { но-аграрный }\end{array}$ \\
\hline
\end{tabular}




\begin{tabular}{|c|c|c|c|c|}
\hline 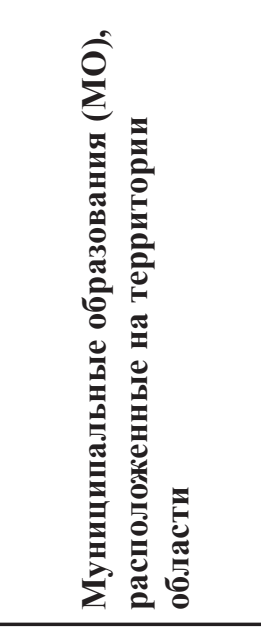 & 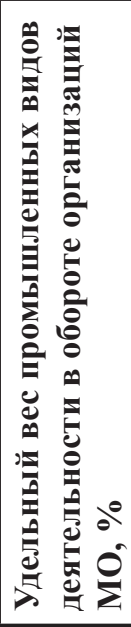 & 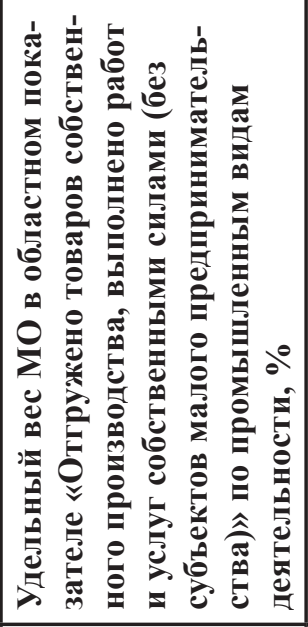 & 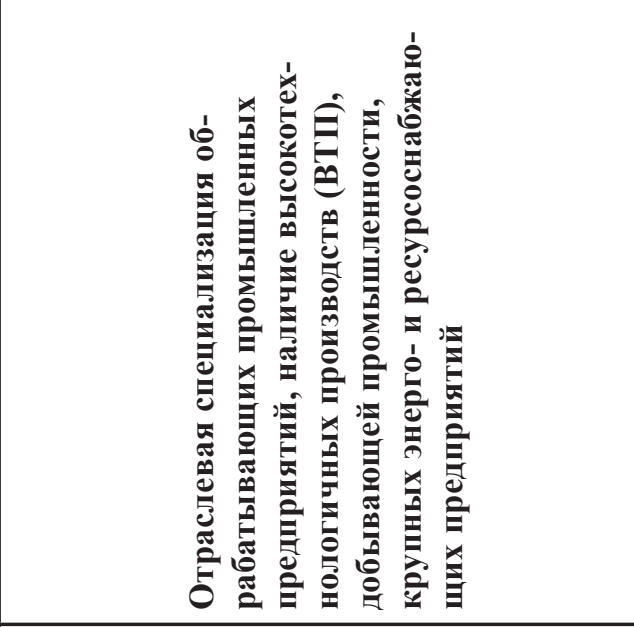 & 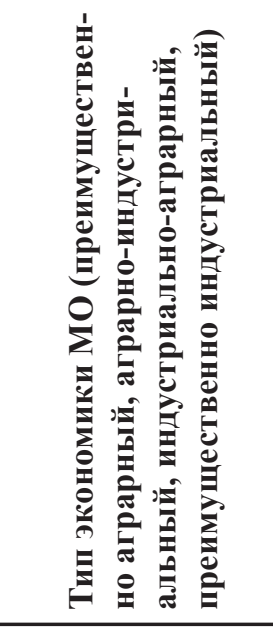 \\
\hline Семилукский & 35,71 & 1,26 & $\begin{array}{l}\text { Добыча полезных ископаемых; } \\
\text { Металлургическое производство и } \\
\text { производство готовых металлических } \\
\text { изделий; } \\
\text { Производство строительных материалов; } \\
\text { Деревообрабатывающее производство }\end{array}$ & $\begin{array}{l}\text { Индустриально- } \\
\text { аграрный }\end{array}$ \\
\hline Таловский & 1,42 & 0,14 & & Аграрный \\
\hline Эртильский & 78,44 & 2,77 & $\begin{array}{l}\text { Производство пищевых продуктов; } \\
\text { Машиностроение (ВТП) }\end{array}$ & $\begin{array}{l}\text { Индустриально- } \\
\text { аграрный }\end{array}$ \\
\hline \multicolumn{5}{|l|}{ Городские округа } \\
\hline Борисоглебский & 56,67 & 3,63 & $\begin{array}{l}\text { Машиностроение (ВТП); } \\
\text { Металлургическое производство и } \\
\text { производство готовых металлических } \\
\text { изделий; } \\
\text { Производство электрооборудования, } \\
\text { электронного и оптического оборудова- } \\
\text { ния (ВТП); } \\
\text { Легкая промышленность; } \\
\text { Производство строительных материалов; } \\
\text { Производство пищевых продуктов }\end{array}$ & $\begin{array}{l}\text { Индустриально- } \\
\text { аграрный }\end{array}$ \\
\hline $\begin{array}{l}\text { город } \\
\text { Нововоронеж }\end{array}$ & 72,37 & 6,4 & $\begin{array}{l}\text { Производство и распределение электроэ- } \\
\text { нергии, газа и воды; } \\
\text { Производство пищевых продуктов; } \\
\text { Производство готовых металлических } \\
\text { изделий; Ремонт машин и оборудования }\end{array}$ & Индустриальный \\
\hline город Воронеж & 39,65 & 36,41 & $\begin{array}{l}\text { Машиностроение (ВТП); } \\
\text { Транспортное машиностроение, в том } \\
\text { числе авиастроение (ВТП); } \\
\text { Производство электрооборудования, } \\
\text { электронного и оптического оборудова- } \\
\text { ния (ВТП); } \\
\text { Химическая промышленность (ВТП); } \\
\text { Производство резиновых и пластмассо- } \\
\text { вых изделий; } \\
\text { Производство строительных материалов; } \\
\text { Металлургическое производство и } \\
\text { производство готовых металлических } \\
\text { изделий; } \\
\text { Легкая промышленность; } \\
\text { Мебельная промышленность; } \\
\text { Производство пищевых продуктов; } \\
\text { Производство и распределение электроэ- } \\
\text { нергии, газа и воды }\end{array}$ & Индустриальный \\
\hline
\end{tabular}


Определение типа экономики муниципального образования (таблица 3) произведено с учетом:

- удельного веса промышленных видов деятельности в обороте организаций муниципального образования $[11$, с. $3 ; 1$, с. $4-19]$;

- удельного веса муниципального образования в областном показателе «Отгружено товаров собственного производства, выполнено работ и услуг собственными силами (без субъектов малого предпринимательства), по промышленным видам деятельности («Добыча полезных ископаемых», «Обрабатывающие производства», «Производство и распределение электроэнергии, газа и воды») [10, с. 8-20];

- отраслевой структуры промышленности на территории муниципального образования (наличие предприятий пищевой и перерабатывающей промышленности, высокотехнологичных промышленных производств и др.).
Таким образом, разработанные типовые модели (рекомендации) промышленного развития отдельных территорий являются актуальными для муниципальных районов, городских округов. Они могут использоваться:

- для подготовки предложений, направленных на стимулирование промышленной деятельности, в зависимости от уровня концентрации промышленного потенциала на территории отдельных муниципальных образований Воронежской области и других субъектов Российской Федерации;

- для рассмотрения территориальных аспектов стандартизации региональной промышленной политики;

- для определения стратегических направлений территориального развития промышленности с позиций кластерного подхода и выявления перспектив межрегионального взаимодействия (например, при принятии решений о создании межрегиональных промышленных кластеров).

\title{
Литература
}

1. Дидикин А. Б., Юдкин А. В. Закон о промышленной политике в России. Экспертный комментарий. М.: Фонд «СЭЦ «Модернизация», 2015. 40 с.

2. О промышленной политике в Воронежской области. Закон Воронежской области от 05.05.2015 № 47-О3 // Портал Воронежской области. Режим доступа: http://pravo.govvrn.ru/?q=node/4093 (дата обращения: 06.05.2015).

3. О промышленной политике в Российской Федерации. Федеральный закон от 31.12.2014 № 488-Ф3// Собрание законодательства РФ. 05.01.2015. № 1. Ч. І. Ст. 41.

4. Об общих принципах организации местного самоуправления в Российской Федерации. Федеральный закон от 06.10.2003 № 131-Ф3 // Собрание законодательства РФ. 06.10.2003. № 40. Ст. 3822.

5. Воробьева Н. А. Формирование и реализация промышленной политики в российской многоуровневой экономике: монография. М-во образования и науки Российской Федерации, Дальневосточный федеральный ун-т, Шк. экономики и менеджмента. Владивосток: Дальневосточный федеральный ун-т, 2015. 175 с.

6. Газимагомедов Р. К. Современная региональная промышленная политика: кластерный подход. Рос. акад. наук, Ин-т мировой экономики и междунар. отношений. М.: ИМЭМО РАН, 2005. 217 с.

7. Евсеев В. О., Скрыль Т. В., Шавина Е. В., Осипов В. С., Невская Н. А. Промышленная политика России. Политэкономические и региональные аспекты. М.: Инфра-М, 2016. 192 с.

8. Пигунова М. В. Исследование проблем стандартизации региональной промышленной политики // Международный научно-исследовательский журнал. 2017. № 7-1. С. 37-41.

9. Пигунова М. В. Стратегическое управление сбалансированным инвестиционным и инновационным развитием обрабатывающей промышленности региона: монография. М.: Мир науки, 2017. 148 с. Режим доступа: http://izd-mn.com/PDF/23MNNPM17.pdf (дата обращения: 01.12.2017).

10. Основные показатели промышленного производства районов Воронежской области за январь-декабрь 2016 года. Статистический бюллетень. Воронеж: Воронежстат, 2017. 34 с.

11. Социально-экономическое положение районов Воронежской области, январь-декабрь 2016 года. Статистический бюллетень. Воронеж: Воронежстат, 2017. 59 с.

\section{STANDARD MODELS (RECOMMENDATIONS) OF DEVELOPMENT FOR TERRITORIES WITH HIGH CONCENTRATION OF INDUSTRIAL POTENTIAL MariaV. Pigunoval,}

\author{
${ }^{1}$ Voronezh State University of Engineering Technologies, 19, Revolution Ave., Voronezh, Russia, 394036 \\ @mpigunova@govvrn.ru
}

Received 08.12.2017. Accepted 17.04.2018. 
Keywords: industry, strategic planning, stimulation mechanisms, territorial development of the industry.

\begin{abstract}
The paper features some topical issues of industrial development strategic planning for territories with high concentration of industrial potential. The author has investigated a role of regional authorities in rendering methodological support to local governments in development of documents of strategic planning in the sphere of the industry: as a result, standard models (recommendations) of development have been defined for certain territories. The research has revealed some features of goal-setting in the sphere of industrial policy and definition of mechanisms of activity stimulation at industrial enterprises on the regional and local levels. This system of indicators allows one to identify types of economy of municipal units (as in the case of the Voronezh region), to characterize their industrial potential, and to give recommendations on stimulation of activity in the sphere of the industry of separate municipal units in the Voronezh region. The author concludes that there is a strong need for coordination when developing strategic planning documents in the sphere of industrial development on the levels of state (federal, regional) and municipal management. Moreover, the author stresses the importance of the regional industrial policy standardization and integrated approach to consideration of territorial aspects.
\end{abstract}

For citation: Pigunova M. V. O razrabotke tipovykh modelei (rekomendatsii) razvitiia otdel'nykh territorii s vysokoi kontsentratsiei promyshlennogo potentsiala [Standard Models (Recommendations) of Development for Territories with High Concentration of Industrial Potential]. Bulletin of Kemerovo State University. Series: Political, Sociological and Economic Sciences, no. 3 (2018): 149-156. DOI:10.21603/2500-3372-2018-3-149-156.

\section{References}

1. Didikin A. B., Iudkin A. V. Zakon o promyshlennoi politike v Rossii. Ekspertnyi kommentarii [Law on Industrial Policy in. Expert commentary]. Moscow: Fond «SETs «Modernizatsiia», 2015, 40.

2. O promyshlennoi politike $v$ Voronezhskoi oblasti [About industrial policy in the Voronezh region]. Law of the Voronezh region of 05.05.2015 No. 47-OZ. Available at: http://pravo.govvrn.ru/?q=node/4093 (accessed 06.05.2015).

3. O promyshlennoi politike $v$ Rossiiskoi Federatsii. Federal'nyi zakon ot 31.12.2014 № 488-FZ [On industrial policy in the Russian Federation. Federal Law of December 31, 2014, No. 488-FZ]. Sobranie zakonodatel'stva RF = Collection of Legislation of the Russian Federation, part I, no. 1 (05.01.2015): art. 41.

4. Ob obshchikh printsipakh organizatsii mestnogo samoupravleniia v Rossiiskoi Federatsii. Federal'nyi zakon ot 06.10.2003 № 131-FZ [On the general principles of the organization of local government in the Russian Federation. Federal Law of October 6, 2003, No. 131-FZ]. Sobranie zakonodatel'stva RF = Collection of Legislation of the Russian Federation, no. 40 (06.10.2003): art. 3822.

5. Vorobeva N. A. Formirovanie $i$ realizatsiia promyshlennoi politiki v rossiiskoi mnogourovnevoi ekonomike [Formation and implementation of industrial policy in the Russian multi-level economy]. Vladivostok: Dal'nevostochnyi federal'nyi un-t, 2015, 175.

6. Gazimagomedov R. K. Sovremennaia regional'naia promyshlennaia politika: klasternyi podkhod [Modern regional industrial policy: cluster approach]. Moscow: IMEMO RAN, 2005, 217.

7. Evseev V. O., Skryl T. V., Shavina E. V., Osipov V. S., Nevskaya N. A. Promyshlennaia politika Rossii. Politekonomicheskie i regional'nye aspekty [Industrial policy of Russia: political economic and regional aspects]. Moscow: Infra-M, 2016, 192.

8. Pigunova M. V. Issledovanie problem standartizatsii regional'noi promyshlennoi politiki [Study of standardization problems in regional industrial policy]. Mezhdunarodnyi nauchno-issledovatel'skii zhurnal = International Research Journal, no. 7-1 (2017): 37-41.

9. Pigunova M. V. Strategicheskoe upravlenie sbalansirovannym investitsionnym i innovatsionnym razvitiem obrabatyvaiushchei promyshlennosti regiona [Strategic management of balanced investment and innovative development of manufacturing industry in the region]. Moscow: Mir nauki, 2017, 148. Available at: http://izd-mn. com/PDF/23MNNPM17.pdf (accessed 01.12.2017).

10. Osnovnye pokazateli promyshlennogo proizvodstva raionov Voronezhskoi oblasti za ianvar'-dekabr'2016 goda [The main indicators of industrial production in the Voronezh region in January-December 2016]. Voronezh: Voronezhstat, 2017, 34.

11. Sotsial'no-ekonomicheskoe polozhenie raionov Voronezhskoi oblasti, ianvar'-dekabr' 2016 goda [The socioeconomic situation in the Voronezh region, January-December 2016]. Voronezh: Voronezhstat, $2017,59$. 